\title{
MÉTODOS QUALITATIVOS DE PESQUISA EM CIÊNCIA DA INFORMAÇÃO
}

VALENTIM, M.L.P. (Org.). Métodos qualitativos de pesquisa em Ciência da Informação. São Paulo: Polis, 2005.
Marta Valentim, intelectual bastante conhecida e respeitada no cenário brasileiro de Ciência da linformação, reúne e organiza, neste livro, seis abordagens sobre métodos qualitativos de pesquisa, já testados e ali descritos pelos autores colaboradores para os interessados da/na área.

Com muita acuidade, Marta, que, além de organizadora da obra, é autora de dois capítulos, intitula o texto de abertura como "Construção do Conhecimento Científico", a partir do qual desdobram-se os demais: "Abordagem cognitiva do Protocolo Verbal na confirmação de termos para a construção de linguagem documentária em inteligência competitiva", "Discurso do Sujeito Coletivo", "A metodologia de Análise de Redes Sociais (ARS)", "Grupo de Foco”, "Análise de Conteúdo", "A Diplomática como perspectiva metodológica para o trata- mento de conteúdo de documentos técnicos". Como fechamento, apresenta-se o texto "Sobre os métodos e as técnicas de pesquisa...", com reflexões instigadoras, provocativas mesmo, sobre a atuação investigativa de alunos, professores e profissionais que atuam na área das Ciências Humanas, especificamente da Ciência da Informação, levantando questões subjacentes e pouco explicitadas.

Como componente da Coleção Palavra-Chave, o livro tem por escopo oferecer “...textos básicos e acessíveis sobre temas relevantes e atuais relacionados com 0 campo da Ciência da Informação". Além de quê, como consta da quarta capa, decorre ele de "...uma demanda advinda de alunos de graduação". 
Entretanto, os seis métodos apresentados relacionam-se com pesquisas que envolveram também graduandos, mas foram coordenados, expostos e descritos por docentes e pesquisadores experientes, com nível de pós-graduação. Assim, não se trata de um mero manual, mas de uma obra que expõe uma excelente diversidade de métodos qualitativos aplicáveis à área, ainda carente de textos que, como um todo, contribuam para seu avanço como ciência em consolidação.

Certamente, o livro organizado por Marta Valentim terá uma influência positiva sobre a ares e deverá incidir tanto no teor das monografias de conclusão de curso, quanto nas opções metodológicas das dissertações de mestrado e, até mesmo, de teses de doutorado.

No bojo de um projeto gráfico prático e visualmente agradável, as cento e setenta e poucas páginas do texto apresentamse em linguagem adequada a um públicoalvo esclarecido, mas não sofisticado ou hermético à intencionalidade da organizadora.

Nos diversos capítulos, encontram-se referências atuais, sempre que possível; quanto à revisão textual, quase não há faIhas, com exceção de umas poucas que podem ter ocorrido por conta de problemas de digitação de certos quadros explicativos e não chegam a prejudicar o conteúdo, recomendável aos que já se envolvem e aos que querem se envolver com pesquisa em Ciência da Informação.

\section{Maria Helena Toledo de Barros Unesp m_helenabarros@hotmail.com}

\section{Title}

Qualitative research methods in Information Science

\section{Título}

Métodos cualitativos de investigación en Ciencia de la Información 